\title{
Detection and Identification of Four Common Rust Pathogens of Cereals and Grasses Using Real-Time Polymerase Chain Reaction
}

\author{
C. W. Barnes and L. J. Szabo
}

United States Department of Agriculture-Agricultural Research Service, Cereal Disease Laboratory, University of Minnesota, Department of Plant Pathology, St. Paul.

Accepted for publication 21 December 2006.

\begin{abstract}
Barnes, C. W., and Szabo, L. J. 2007. Detection and identification of four common rust pathogens of cereals and grasses using real-time polymerase chain reaction. Phytopathology 97:717-727.

Puccinia spp. are widespread pathogens of cereals and grasses that annually cause significant yield losses worldwide, especially in barley, oat, and wheat. Urediniospore morphology and early symptom development have limited usefulness for distinguishing Puccinia spp. Therefore, we developed real-time polymerase chain reaction assays for rapid detection of the four rust pathogen species, Puccinia graminis (Pers.:Pers.), P. striiformis (Westend.), P. triticina (Eriks.), and P. recondita (Roberge ex Desmaz.). Duplex assays were constructed for the nuclear rDNA gene,

using the variable internal transcribed spacer 1 (ITS1) region to distinguish between species, and the conserved $28 \mathrm{~S}$ region as an internal control. Species-specific ITS1 primer/probe sets were highly specific and could detect $<1 \mathrm{pg}$ of DNA. The species-specific primer/probe sets showed positive results over a linear range of DNA five orders of magnitude or greater. Specificity of the assays was tested using multiple collections representing a range of races and formae speciales within a species. Additionally, assay specificity was evaluated by testing a range of other grass rust pathogens, as well as other fungi. The $28 \mathrm{~S}$ primer/probe combination was successful in detecting all Puccinia spp. tested within the duplex assays, validating the integrity of each assay. Finally, the assays were used to identify unknown rust fungi infecting pasture grasses.
\end{abstract}

Puccinia spp. are important pathogens of many grasses, but are most notorious for the destructiveness on grain crops, especially wheat. Three Puccinia spp. are responsible for the majority of wheat losses: Puccinia graminis, $P$. striiformis, and $P$. triticina (37). However, although $P$. triticina is restricted to infecting wheat, $P$. graminis $(15,34)$ and $P$. striiformis $(19,30,33)$ have a relatively broad host range that includes pasture grasses and other wild grass species. Rapid detection and correct identification are important for an increased understanding of the epidemiology of rust diseases of cereal crops and pasture grasses, and for the study of naturally occurring populations of these rust pathogens.

Available methods to detect and verify a given rust fungal species are often imprecise or slow. Rust fungal species are difficult to identify in early stages of disease development, on natural grass hosts, or by urediniospore morphology. Although uredinia of some species become distinctive following a week to 10 days of disease development ( $P$. graminis), others are not. Molecular methods, such as conventional polymerase chain reaction (PCR) with Southern hybridization or sequence analysis, can be useful at any stage of development, but are often labor intensive and can require several days to confirm the identity of a sample $(11,24$, 27). Furthermore, sequence-based methods are limited by low DNA concentrations. Real-time PCR with fluorogenic probes is used to detect and quantify plant pathogens rapidly $(8,9,14,26$, 38). The advantages of real-time PCR with a fluorogenic probe are that it adds additional specificity beyond the primers, increases sensitivity of PCR through fluorescence detection, and negates the need for post-PCR analysis $(6,20,29)$.

A commonly reported genomic region employed to distinguish fungal species based on sequence differences is nuclear ribosomal

Corresponding author: C. W. Barnes; E-mail address: barn0107@umn.edu

doi:10.1094/PHYTO-97-6-0717

This article is in the public domain and not copyrightable. It may be freely reprinted with customary crediting of the source. The American Phytopathological Society, 2007.
DNA (rDNA) $(5,9,12,14,21,28,32,40)$. The advantages of this region are that it is highly repetitive (24), the rDNA sequences for many fungi are publicly available, and the internal transcribed spacer (ITS) regions evolve relatively quickly (36), making distinction between Puccinia spp. possible (40). Confidence in the specificity of a real-time PCR assay depends on knowledge of the variation in the DNA sequence both within the target organism and between the target and closely related nontarget organisms.

The objective of this study was to develop a real-time PCR system to rapidly detect and identify rust fungal species when conventional identification by disease symptom or spore morphology is not possible, or in instances when only a limited number of spores are available, such as from rain or air collectors. The concept in the assay design was to employ species-specific fluorogenic probes and general rust-fungus-specific primers and PCR conditions. In this study, we developed species-specific real-time PCR assays for the independent detection of four common rust fungi that infect cereals and grasses, $P$. graminis, $P$. striiformis, and $P$. triticina; and $P$. recondita $\mathrm{f}$. sp. secalis, which infects rye (Secale cereale L.) and wild relatives of wheat (Aegilops spp.). Each assay consisted of (i) rust-fungus-specific primers for the ITS1 region and Puccinia spp.-specific TaqMan 6-carboxy-fluorescein (FAM) probes and (ii) general primers for the $28 \mathrm{~S}$ region and a nonspecies-specific TaqMan TexasRed probe as an internal positive control.

\section{METHODS}

Puccinia spp. used for assay development. Puccinia spp. samples were used for two purposes in this study: (i) to obtain DNA sequences for interspecific and intraspecific alignments for primer and probe design and (ii) to validate the specificity of the real-time PCR assays. Fungal samples used in this study are shown in Table 1. Puccinia spp. samples for both purposes were chosen to be representative of a broad population of each rust fungal species and included samples that varied by where and when they were collected, by host, and by race, when applicable. 
DNA extraction. DNA was extracted from either collected, dried urediniospores (1 to $20 \mathrm{mg}$ ) or from diced, infected leaf tissue with visible uredinia (20 to $30 \mathrm{mg}$ ). All samples were shaken in 2-ml tubes with $1 \mathrm{~mm}$ of glass beads (Lysing Matrix C; Bio 101, Carlsbad, CA) and $25 \mathrm{mg}$ of diatomaceous earth (SigmaAldrich, St. Louis) in a Savant FastPrep shaker (FP120; Holbrook, NY) for $10 \mathrm{~s}$ at a speed setting of 5 (2). DNA was extracted using the following modifications of the cetyltrimethylam- monium bromide (CTAB) method described by Liu and Kolmer (16) and Anikster et al. (2). Following incubation at $65^{\circ} \mathrm{C}$ for $1.5 \mathrm{~h}$ in $600 \mu \mathrm{l}$ of extraction buffer $(0.165 \mathrm{M}$ Tris- $\mathrm{HCl}, \mathrm{pH} 8.0 ; 66 \mathrm{mM}$ EDTA, pH 8.0; $1.54 \mathrm{M} \mathrm{NaCl} ; 1.1 \% \mathrm{CTAB}$; and Proteinase $\mathrm{K}$ at $50 \mu \mathrm{g} / \mathrm{ml}$ ) and $66 \mu \mathrm{l}$ of $20 \%$ sodium dodecyl sulfate, samples were extracted with an equal volume of phenol:chloroform:isoamyl alcohol (25:24:1, vol/vol/vol), followed by extraction with an equal volume of chloroform:isoamyl alcohol $(24: 1, \mathrm{vol} / \mathrm{vol})$. The aque-

TABLE 1. List of fungal samples used in this study

\begin{tabular}{|c|c|c|c|c|c|c|}
\hline Species & Race & Host & Origin & Source $^{\mathrm{a}}$ & Year & GenBank accession no. \\
\hline \multicolumn{7}{|l|}{ Rust fungi } \\
\hline \multicolumn{7}{|l|}{ Puccinia graminis } \\
\hline $57 \mathrm{KS} 17-2 \mathrm{C}$ & $\mathrm{MCCF}$ & Triticum aestivum & Kansas & 1 & 1957 & DQ417374 \\
\hline 61PA80A & RFQQ & T. aestivum & Pennsylvania & 1 & 1961 & DQ417373 \\
\hline 80MN518-3 & RKRQ & T. aestivum & Minnesota & 1 & 1980 & DQ417376 \\
\hline $590 \mathrm{H} 5 \mathrm{~B}$ & QCCQ & T. aestivum & Ohio & 1 & 1959 & DQ417375 \\
\hline 70MEX3A & RTHJ & T. aestivum & Mexico & 1 & 1970 & DQ417377 \\
\hline 89OR436B & QFCS & T. aestivum & Oregon & 1 & 1989 & DQ417380 \\
\hline $68 \mathrm{MO} 192-1 \mathrm{~A}$ & RHTS & T. aestivum & Missouri & 1 & 1968 & DQ417379 \\
\hline 61IA21C & TPMK & T. aestivum & Iowa & 1 & 1961 & DQ417378 \\
\hline HSZ0009 & $\ldots$ & Elymus trachycalus & Wisconsin & 1 & 2001 & DQ417381 \\
\hline HSZ0931 & $\ldots$ & T. aestivum & Switzerland & 1 & 2003 & DQ417387 \\
\hline HSZ0679 & $\ldots$ & T. aestivum & Czech Republic & 2 & 2002 & DQ417382 \\
\hline HSZ0920 & $\ldots$ & Phleum pratense & Minnesota & 1 & 2001 & DQ417392 \\
\hline HSZ0922 & $\ldots$ & Elytrigia repens & Switzerland & 1 & 2003 & DQ417388 \\
\hline HSZ0929 & $\ldots$ & Poa pratensis & Switzerland & 1 & 2003 & DQ417389 \\
\hline HSZ0928 & $\ldots$ & Dactylis glomerata & Switzerland & 1 & 2003 & DQ417390 \\
\hline HSZ0926 & $\ldots$ & Avena sativa & Switzerland & 1 & 2003 & DQ417391 \\
\hline $78-21-B B 463^{b}$ & DFBJ & T. aestivum & Pennsylvania & 1 & 1978 & AY $114289^{c}$ \\
\hline $56 \mathrm{SD} 37 \mathrm{~B}^{\mathrm{b}}$ & RCRS & T. aestivum & South Dakota & 1 & 1956 & DQ417383 \\
\hline $\mathrm{HSZ} 0802^{\mathrm{b}}$ & $\ldots$ & Lolium perenne & Oregon & 1 & 2003 & DQ417384 \\
\hline $\mathrm{HSZ}_{0803^{\mathrm{b}}}$ & $\ldots$ & Festuca arundinacea & Oregon & 1 & 2003 & DQ417385 \\
\hline HSZ0753 ${ }^{\mathrm{b}}$ & $\ldots$ & Anthroxanthum spp. & Czech Republic & 2 & 2003 & DQ417386 \\
\hline 84FL680 & RCRS & T. aestivum & Florida & 1 & 1984 & $\ldots$ \\
\hline $74 \mathrm{KS} 264 \mathrm{~A}^{\mathrm{b}}$ & TPMK & T. aestivum & Kansas & 1 & 1974 & $\ldots$ \\
\hline $80 \mathrm{MN} 633 \mathrm{~B}^{\mathrm{b}}$ & TPMK & T. aestivum & Minnesota & 1 & 1980 & $\ldots$ \\
\hline $75 \mathrm{WA} 205 \mathrm{~A}^{\mathrm{b}}$ & RHTS & T. aestivum & Washington & 1 & 1975 & $\ldots$ \\
\hline $91 \mathrm{MEX} 647^{\mathrm{b}}$ & RTRQ & T. aestivum & Mexico & 1 & 1991 & $\ldots$ \\
\hline 72CAN1321 $\mathrm{A}^{\mathrm{b}}$ & MCCD & T. aestivum & Canada & 1 & 1972 & $\ldots$ \\
\hline $73 \mathrm{VA} 441 \mathrm{~A}^{\mathrm{b}}$ & MCCD & T. aestivum & Virginia & 1 & 1973 & $\ldots$ \\
\hline $93 \mathrm{NY} 224 \mathrm{~B}^{\mathrm{b}}$ & QFCS & T. aestivum & New York & 1 & 1993 & $\ldots$ \\
\hline $91 \mathrm{KS} 60 \mathrm{~A}^{\mathrm{b}}$ & QFCS & T. aestivum & Kansas & 1 & 1991 & $\ldots$ \\
\hline $91 \mathrm{WA} 496 \mathrm{~A}^{\mathrm{b}}$ & QFCS & T. aestivum & Washington & 1 & 1991 & $\cdots$ \\
\hline \multicolumn{7}{|l|}{ P. recondita } \\
\hline $80 \mathrm{WV} 271^{\mathrm{b}}$ & $\ldots$ & Secale cereale & West Virginia & 1 & 1980 & DQ417420 \\
\hline $82 \mathrm{WI} 47^{\mathrm{b}}$ & $\ldots$ & S. cereale & Wisconsin & 1 & 1982 & DQ417421 \\
\hline $91 \mathrm{TX} 9503^{\mathrm{b}}$ & $\ldots$ & S. cereale & Texas & 1 & 1991 & DQ417422 \\
\hline HSZ0698 b & $\ldots$ & S. cereale & Czech Republic & 2 & 2002 & DQ417423 \\
\hline ANK9958 & $\ldots$ & Aegilops ovata & Israel & 3 & 2002 & DQ417424 \\
\hline ANK9974b & $\ldots$ & A. variabilis & Israel & 3 & 2003 & AY $187088^{c}$ \\
\hline HSZ0716 & $\ldots$ & S. cereale & California & 1 & 2003 & DQ417425 \\
\hline HSZ0712 & $\ldots$ & S. cereale & California & 1 & 2003 & DQ417426 \\
\hline ANK77081 & $\ldots$ & T. turgidum spp. durum & Israel & 3 & 2002 & AF511082c \\
\hline \multicolumn{7}{|l|}{ P. striiformis } \\
\hline PSH13 & $\ldots$ & Hordeum vulgare & Washington & 4 & 2001 & DQ417408 \\
\hline PSH14 ${ }^{\mathrm{b}}$ & $\ldots$ & H. vulgare & Washington & 4 & 2001 & DQ417393 \\
\hline PST17 & $\ldots$ & T. aestivum & Washington & 4 & 2001 & DQ417394 \\
\hline PST29b & $\ldots$ & T. aestivum & Washington & 4 & 2001 & DQ417395 \\
\hline PST78 $^{\mathrm{b}}$ & $\ldots$ & T. aestivum & Washington & 4 & 2001 & DQ417396 \\
\hline $22 / 99$ & $\ldots$ & T. aestivum & Denmark & 5 & 1999 & DQ417397 \\
\hline HSZ0728 & $\ldots$ & T. aestivum & Texas & 1 & 2003 & DQ417398 \\
\hline HSZ0727 & $\ldots$ & T. aestivum & Texas & 1 & 2003 & DQ417399 \\
\hline HSZ0725 & $\ldots$ & T. aestivum & Texas & 1 & 2003 & DQ417400 \\
\hline HSZ0718 & $\ldots$ & T. aestivum & Texas & 1 & 2003 & DQ417401 \\
\hline HSZ0711 & $\ldots$ & H. vulgare & California & 1 & 2003 & DQ417402 \\
\hline \multirow[t]{2}{*}{ HSZ0699 } & $\ldots$ & Dactylis glomerata & Czech Republic & 2 & 2002 & DQ417403 \\
\hline & & & & & & (continued on next \\
\hline
\end{tabular}

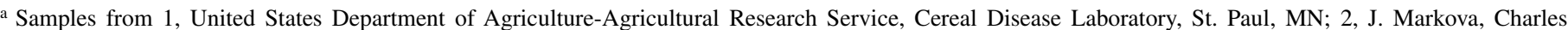
University, Prague; 3, Y. Anikster, Institute of Cereal Crops Improvement, Tel Aviv, Israel; 4, X. Chen, United States Department of Agriculture-Agricultural Research Service, Wheat Genetics, Quality, Physiology and Disease Research, Pullman, WA; 5, A. F. Justesen, Faculty of Agricultural Sciences, Flakkebjerg, Denmark, DNA; 6, A. del Olmo, CIFA, Córdoba, Spain, DNA; and 7, P. Hamm, Oregon State University, Hermiston.

${ }^{b}$ Rust fungal species used for assay verification.

c Previous submissions to GenBank.
} 
ous phase was removed, and nucleic acids were precipitated with 0.6 volume of isopropanol and finally resuspended in $100 \mu \mathrm{l}$ of Tris-EDTA (TE) buffer (10 mM Tris-HCl, pH 8.0; 0.1 mM EDTA, $\mathrm{pH}$ 8.0). RNA was digested by incubation with $3.5 \mu$ of RNase A $\left(10 \mathrm{mg} \mathrm{ml}^{-1}\right)$ at $37^{\circ} \mathrm{C}$ for $1 \mathrm{~h}$. To precipitate DNA, 0.1 volume of $3.0 \mathrm{M} \mathrm{NaOAc}$ and 2.0 volumes of cold $95 \%$ ethanol were added to samples, mixed by inversion, and incubated at $-20^{\circ} \mathrm{C}$ for $1 \mathrm{~h}$. After centrifugation, the pellet then was washed twice with cold $70 \%$ ethanol, air dried, and resuspended in $100 \mu \mathrm{l}$ of TE buffer. The
DNA was quantified using a DyNA Quant200 Fluorometer (Hoefer Inc., San Francisco)) and verified by electrophoresis through an agarose gel. DNA from uninfected wheat (Triticum aestivum) was provided by David Gavin of the United States Department of Agriculture-Agricultural Research Service, Plant Science Research Unit, St. Paul, MN.

DNA sequencing. rDNA was PCR amplified in a 50- $\mu$ l reaction mixture as described in Anikster et al. (2). DNA sequencing reactions were performed using a Thermo Sequencase Prime

TABLE 1. (continued from preceding page)

\begin{tabular}{|c|c|c|c|c|c|c|}
\hline Species & Race & Host & Origin & Source $^{\mathrm{a}}$ & Year & GenBank accession no. \\
\hline \multicolumn{7}{|l|}{ P. striiformis (continued) } \\
\hline HSZ0010 & $\ldots$ & Poa pratensis & Georgia & 1 & 2001 & DQ417407 \\
\hline $52 / 99^{\mathrm{b}}$ & $\ldots$ & T. aestivum & Denmark & 5 & 1999 & DQ417404 \\
\hline HSZ0722 $2^{b}$ & $\ldots$ & T. aestivum & Texas & 1 & 2003 & DQ417405 \\
\hline HSZ0724 ${ }^{\mathrm{b}}$ & $\ldots$ & T. aestivum & Texas & 1 & 2003 & DQ417406 \\
\hline $\mathrm{PSH} 31^{\mathrm{b}}$ & $\ldots$ & H. vulgare & Washington & 4 & 2001 & $\ldots$ \\
\hline \multicolumn{7}{|l|}{ P. triticina } \\
\hline HSZ0741 & $\ldots$ & T. aestivum & Czech Republic & 1 & 2002 & DQ417409 \\
\hline HSZ0742 & $\ldots$ & T. aestivum & Czech Republic & 1 & 2002 & DQ417410 \\
\hline HSZ0743 & $\ldots$ & T. aestivum & Czech Republic & 1 & 2002 & DQ417411 \\
\hline HSZ0744 & $\ldots$ & T. aestivum & Czech Republic & 1 & 2002 & DQ417412 \\
\hline HSZ0745 & $\ldots$ & T. aestivum & Slovakia & 1 & 2002 & DQ417413 \\
\hline HSZ0746 & $\ldots$ & T. aestivum & Slovakia & 1 & 2002 & DQ417414 \\
\hline HSZ0747 & $\ldots$ & T. aestivum & Slovakia & 1 & 2002 & DQ417415 \\
\hline HSZ0748 & $\ldots$ & T. aestivum & Czech Republic & 1 & 2002 & DQ417416 \\
\hline ANK9973 & $\ldots$ & T. turgidum spp. durum & Israel & 3 & 2002 & DQ417417 \\
\hline ANK9538 & $\ldots$ & T. aestivum & Israel & 3 & 2002 & DQ417418 \\
\hline 00LA87 & $\ldots$ & T. aestivum & Louisiana & 1 & 2000 & AF511083c \\
\hline $98 \mathrm{EGY} 166 \mathrm{C}^{\mathrm{b}}$ & MCDLQS & T. aestivum & Egypt & 1 & 1998 & AY $187087^{c}$ \\
\hline $98 \mathrm{EGY} 151 \mathrm{C}^{\mathrm{b}}$ & PCBCLS & T. aestivum & Egypt & 1 & 1998 & DQ417419 \\
\hline $99 \mathrm{NC} 28-1^{\mathrm{b}}$ & TLGF & T. aestivum & North Carolina & 1 & 1999 & $\ldots$ \\
\hline 93 WA $504^{\mathrm{b}}$ & NBBJ & T. aestivum & Washington & 1 & 1993 & $\ldots$ \\
\hline $82 \mathrm{TX} 176^{\mathrm{b}}$ & FLLQ & T. aestivum & Texas & 1 & 1982 & $\ldots$ \\
\hline $82 \mathrm{MN} 246^{\mathrm{b}}$ & TDBJ & T. aestivum & Minnesota & 1 & 1982 & $\ldots$ \\
\hline $87 \mathrm{NY} 678^{\mathrm{b}}$ & PBMQ & T. aestivum & New York & 1 & 1987 & $\ldots$ \\
\hline $00 \mathrm{CA} 135^{\mathrm{b}}$ & MBGJ & T. aestivum & California & 1 & 2000 & $\ldots$ \\
\hline $90 \mathrm{KS} 285^{\mathrm{b}}$ & MGBD & T. aestivum & Kansas & 1 & 1990 & $\ldots$ \\
\hline 00EGY38B ${ }^{\mathrm{b}}$ & MCNLQS & T. aestivum & Egypt & 1 & 2000 & $\ldots$ \\
\hline $00 \mathrm{EGY} 200 \mathrm{C}^{\mathrm{b}}$ & LBBLBQ & T. aestivum & Egypt & 1 & 2000 & $\ldots$ \\
\hline 98IL324b & MDRQ & T. aestivum & Illinois & 1 & 1998 & $\ldots$ \\
\hline 98AR243 ${ }^{\mathrm{b}}$ & MDRQ & T. aestivum & Arkansas & 1 & 1998 & $\ldots$ \\
\hline 99SPN40AO & $\ldots$ & T. durum & Spain & 6 & 1999 & $\ldots$ \\
\hline \multicolumn{7}{|l|}{ P. andropogonis } \\
\hline HSZ0261b & $\ldots$ & Andropogon gerardii & Wisconsin & 1 & 2001 & $\ldots$ \\
\hline HSZ0222b & $\ldots$ & A. gerardii & Minnesota & 1 & 2002 & $\ldots$ \\
\hline HSZ0237 & $\ldots$ & A. gerardii & Minnesota & 1 & 2002 & $\ldots$ \\
\hline $\mathrm{HSZ} 0227^{\mathrm{b}}$ & $\cdots$ & Schizachyrium scopari & Minnesota & 1 & 2002 & $\cdots$ \\
\hline \multicolumn{7}{|l|}{ Unknown } \\
\hline HSZ0882 & $\ldots$ & Tall pasture grass & Oregon & 7 & 2003 & $\ldots$ \\
\hline HSZ0883 ${ }^{\mathrm{b}}$ & $\ldots$ & Wide blade grass & Oregon & 7 & 2003 & $\ldots$ \\
\hline HSZ0884 ${ }^{\mathrm{b}}$ & $\ldots$ & Tall pasture grass & Oregon & 7 & 2003 & $\ldots$ \\
\hline HSZ0885 & $\ldots$ & Tall pasture grass & Oregon & 7 & 2003 & $\ldots$ \\
\hline HSZ0886 ${ }^{\mathrm{b}}$ & $\ldots$ & Poa pratensis & Oregon & 7 & 2003 & $\ldots$ \\
\hline HSZ0887b & $\ldots$ & Wide blade grass & Oregon & 7 & 2003 & $\ldots$ \\
\hline \multicolumn{7}{|l|}{ P. bromina } \\
\hline HSZ0663 ${ }^{b}$ & $\ldots$ & Bromus inermis & Czech Republic & 2 & 2002 & $\ldots$ \\
\hline HSZ0664 & $\ldots$ & B. inermis & Czech Republic & 2 & 2002 & $\ldots$ \\
\hline \multicolumn{7}{|l|}{ P. arrhenathericola } \\
\hline HSZ0659 & $\ldots$ & Arrhenatherum elatius & Slovakia & 2 & 2002 & $\ldots$ \\
\hline \multicolumn{7}{|l|}{ P. triseti } \\
\hline HSZ0700 & $\ldots$ & Trisetum flavescens & Czech Republic & 2 & 2002 & $\ldots$ \\
\hline \multicolumn{7}{|l|}{ P. coronata } \\
\hline $\mathrm{HSZ0425^{ \textrm {b } }}$ & $\ldots$ & Rhammus catharticus & Slovakia & 2 & 2002 & $\ldots$ \\
\hline \multicolumn{7}{|l|}{ P. persistens } \\
\hline HSZ0688 & $\ldots$ & Elytrigia intermedia & Czech Republic & 2 & 2002 & $\ldots$ \\
\hline Tranzschelia fusca ${ }^{\mathrm{b}}$ & $\ldots$ & Anemone quinquefolia & Minnesota & 1 & 2003 & $\ldots$ \\
\hline T. pruni-spinosae ${ }^{\mathrm{b}}$ & $\ldots$ & A. quinquefolia & Minnesota & 1 & 2003 & $\ldots$ \\
\hline \multicolumn{7}{|l|}{ Other fungi } \\
\hline Ustilago maydis & $\ldots$ & Zea mays & Minnesota & 1 & 1998 & $\ldots$ \\
\hline Fusarium graminearum & $\ldots$ & Triticum aestivum & Minnesota & 1 & 2003 & $\ldots$ \\
\hline
\end{tabular}


Cycle sequencing kit (Amersham Biosciences, Piscataway, NJ) and analyzed on an automated DNA sequencer (LI-COR, Lincoln, $\mathrm{NE}$ ). Three or more clones were sequenced for each sample, and the DNA sequence data was assembled and edited with Sequencer (Genecodes, Ann Arbor, MI). Nucleotide sequence data have been submitted to GenBank, with the accession numbers listed in Table 1 .

Primer and probe design. Primer and probe sequences are shown in Table 2. Sequence alignments of the rDNA region of Puccinia spp. were used to design two pairs of oligonucleotide primers. The first primer pair, ITS1rustF10d and ITS1rustR3c, amplify the ITS1 region, producing rust-fungus-specific fragments ranging from 260 to $270 \mathrm{bp}$ among the four Puccinia spp. (data not shown). The second primer pair, StdLSUF5a and StdLSUR2a, was used as an internal standard control and amplified the highly conserved $28 \mathrm{~S}$ large subunit (LSU) region. To distinguish among the four Puccinia spp., species-specific TaqMan probes were designed in the ITS1 region, each labeled at the 5' end with the reporter dye FAM and the fluorescent quencher dye 6-carboxy-tetramethylrhodamine (TAMRA) at the $3^{\prime}$ end (IDT, Coralville, IA). A probe to the conserved $28 \mathrm{~S}$ region sequence was designed as an internal standard for fungal rDNA. The ITS1 primers and probe and the StdLSU primers and probe were combined in a single-tube duplex assay for each species. The internal standard TaqMan fluorogenic probe was labeled at the 5' end with the reporter dye TexasRed-X (succinimidyl ester) (Invitrogen, Carlsbad, CA,) and at the $3^{\prime}$ end with the fluorescent quencher dye BHQ-2 (poly-azo poly-aromatic compound) (Biosearch Technologies, Inc., Novato, CA). All primer pairs and the corresponding probes were designed by comparing sequence alignments for Puccinia spp. listed in Table 1 using MacVector (version 7.2; MacVector Inc., Cary, NC).

Real-time PCR conditions and analysis. Reactions were performed using a SmartCycler (Cepheid, Sunnyvale, CA) in $25-\mu l$ Cepheid tubes. Optimal conditions were determined by performing the real-time assays with concentration gradients of primers $(300,600$, and $1,000 \mathrm{nM})$ and $\mathrm{MgCl}_{2}(0.5$ to $4.0 \mathrm{mM})$ at different annealing temperatures $\left(58\right.$ to $\left.64^{\circ} \mathrm{C}\right)$. The threshold cycle $\left(\mathrm{C}_{\mathrm{T}}\right)$ value was recorded for each dye as the cycle at which the fluorescent signal, associated with an exponential amplification of the PCR product, intersects the threshold set at 30. Conditions were considered optimal if they produced the lowest $\mathrm{C}_{\mathrm{T}}$ values and the highest fluorescence over all four Puccinia assays. The final reaction conditions used in this study consisted of $25-\mu l$

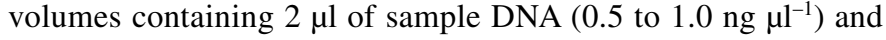
$23 \mu \mathrm{l}$ of a master mix containing $1.0 \mu \mathrm{M}$ each of the four primers, $0.2 \mu \mathrm{M}$ both TaqMan fluorogenic probes, $0.2 \mu \mathrm{M}$ dNTPs, $1 \times$ PCR buffer, $2 \mathrm{mM} \mathrm{MgCl}, 0.625$ units of Taq polymerase (Applied Biosystems, Branchburg, NJ), and $0.005 \%$ casein. Amplification of all samples was based on the following conditions: initial denaturation at $95^{\circ} \mathrm{C}$ for $2 \mathrm{~min}$, followed by 45 cycles of $95^{\circ} \mathrm{C}$ for $15 \mathrm{~s}$, $60^{\circ} \mathrm{C}$ for $30 \mathrm{~s}$, and $72^{\circ} \mathrm{C}$ for $30 \mathrm{~s}$. Assay results were represented graphically by exporting data points from the SmartCycler software and importing them into DeltaGraph 5.6 (Red Rock Software, Salt Lake City, UT).

Assay sensitivity and specificity. Sensitivity limits were determined using genomic DNA starting at 1 to $10 \mathrm{ng}$ and serially diluted 10-fold until the target DNA could not be detected. Standard curves for each Puccinia spp. were generated by plotting the $\log$ of the known DNA concentration on the $y$ axis against the $\mathrm{C}_{\mathrm{T}}$ value generated by the second derivative (2nd derivative- $\mathrm{C}_{\mathrm{T}}$ ) on the $x$ axis. The second derivative is the measure of the rate of increase of the amplicon, measured as the increase in fluorescence. The 2 nd derivative- $C_{T}$ is the cycle at which the greatest increase in fluorescence occurred. The simple linear regression line and coefficient of determination $\left(r^{2}\right)$ were calculated by the SmartCycler software within a single experiment. Real-time PCR reaction efficiency was measured by the slope of the line of the log of sample dilutions of known DNA concentrations plotted against the 2nd derivative- $\mathrm{C}_{\mathrm{T}}$ values as $\mathrm{E}=\left(10^{\text {(-slope) }}-1\right) * 100$, with the $2 \mathrm{nd}$ derivative- $\mathrm{C}_{\mathrm{T}}$ value on the $x$ axis. In this study, reaction efficiency was monitored mainly as a measure of PCR inhibition in any reaction when a series of DNA concentrations were known.

FAM probe specificity was considered true only if there was a positive $\mathrm{C}_{\mathrm{T}}$ for DNA from all isolates of a given species and a zero $\mathrm{C}_{\mathrm{T}}$ for all other DNA tested. In all, $1 \mathrm{ng}$ to $\approx 500 \mathrm{pg}$ of DNA for each sample was used to determine assay specificity. Amplification for both primer pairs was confirmed by agarose gel electrophoresis.

Assay application. In the fall of 2004, six samples of rust fungi infecting five unknown pasture grass hosts received preliminary identification in the field and by light microscopy. To confirm the species identity of the rust fungus from each sample, real-time PCR assays were performed and PCR amplicons were cloned and sequenced.

\section{RESULTS}

Primer and probe design. In order to increase our confidence in the specificity of the primers and probes, the ITS region of a wide collection of samples was sequenced (Table 1). A segment of $\approx 1,300 \mathrm{bp}$ containing the $5^{\prime}$ end of the $18 \mathrm{~S}$ complete ITS region and $5^{\prime}$ end of the $28 \mathrm{~S}$ rDNA was sequenced for 20 samples of $P$. graminis, 7 samples of $P$. recondita $\mathrm{f}$. sp. secalis, 16 samples of $P$. striiformis, and 11 samples of $P$. triticina. The sequence alignment showed ITS1 to have a higher level of variation than ITS2; therefore, this region was used for primer and probe design.

The primer pair of the regions flanking the ITS1 (ITS1rustF10d and ITS1rustR3c) amplified all the rust fungal species tested (Table 3), but did not amplify Ustilago maydis, Fusarium graminearum, or T. aestivum (Fig. 1A). Design of species-specific FAM probes was based on selective sites identified to maximize

TABLE 2. Polymerase chain reaction primer and fluorescent probe sequences used in this study

\begin{tabular}{|c|c|c|c|}
\hline Primer/probe & Sequence $\left(5^{\prime}-3^{\prime}\right)$ & $\operatorname{Tm}\left({ }^{\circ} \mathrm{C}\right)^{\mathrm{a}}$ & Location $(b p)^{b}$ \\
\hline ITS1rustF10d & TGAACCTGCAGAAGGATCATTA & 51.6 & $47-68$ \\
\hline ITS1rustR3c & TGAGAGCCTAGAGATCCATTGTTA & 51.9 & $293-316$ \\
\hline StdLSUF5a & CGTGAGGGAAAGATGAAAAGAA & 52.8 & $1,009-1,030$ \\
\hline StdLSUR2a & AGACTGCTACATTTCCTTAAACCC & 52.1 & $1,173-1,196$ \\
\hline Pg FAM $1^{\mathrm{c}}$ & FAM-TTGTGGCTCGACTCTCTTATAAACCAAACC-TAMRA & 68.6 & $93-122$ \\
\hline Pr FAM $2^{\mathrm{c}}$ & FAM-TTACCCAACTTTACCAAGACTTCTTTGCATGA-TAMRA & 69.3 & $117-148$ \\
\hline Ps FAM $2^{c}$ & FAM-TAAGACTTGGTTGCATGATTTGAAAGAATCATT-TAMRA & 68.5 & $132-164$ \\
\hline Pt FAM $4^{\mathrm{c}}$ & FAM-TGAAAGAATCATTGTGATTAAGTATACGTGGCATTCT-TAMRA & 70.0 & $150-186$ \\
\hline StdLSUTex1 & Texas Red-AGGGAGTATTCTAATGATTAACAGACCAACATCA-BHQ2 & 67.0 & $1,120-1,153$ \\
\hline
\end{tabular}

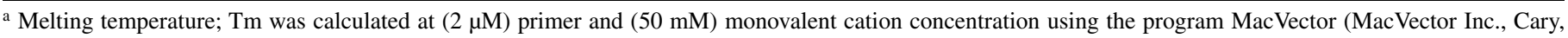
NC).

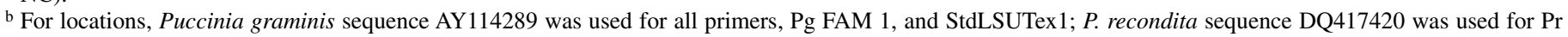
FAM 2; P. striiformis sequence DQ417393 was used for Ps FAM 2; and P. triticina sequence AY187087 was used for Pt FAM 4.

${ }^{c}$ Pg FAM $1=P$. graminis probe, Pr FAM $2=P$. recondita probe, Ps FAM $2=P$. striiformis probe, and Pt FAM $4=P$. triticina probe. 
sequence differences between the four Puccinia spp. Of the roughly 260- to 270-bp region of ITS1, all probes fell into a 97-bp region starting at base pair 47 through base pair 144 (Table 2). This region was devoid of polynucleotide repeats and, most importantly, was able to distinguish between the four rust pathogens (Fig. 2). Furthermore, among the diversity of collections within each fungal species, each FAM probe successfully detected only the rust fungal species it was designed to detect (Table 3 ).

An internal standard primer pair and probe combination was developed to verify the integrity of the PCR reaction and control against reporting false negative reactions. Like the ITS 1 primer pair, the 28S primer pair, StdLSUF5a and StdLSUR2a, amplified only DNA from rust fungi, and did not amplify DNA from $U$. maydis, F. graminearum, or T. aestivum (Fig. 1B). However, the 28S primers did not amplify DNA from Tranzschelia fusca or $T$. arthurii (Table 3) and, therefore, has a more narrow range than the ITS1 primer pair. Although the StdLSUF5a and StdLSUR2a primer pair successfully amplified DNA, positive $C_{T}$ values for all rust fungal DNA samples were obtained using the TexasRed probe whether the ITS1-specific FAM probe was positive or not (Table 3).

Assay sensitivity. The sensitivity of the real-time PCR assay was evaluated through serial dilutions of genomic DNA standards of known concentrations. Linearity of the standard curves extended over an at least $10^{5}$-fold range of DNA concentrations with an $r^{2}$ of $\geq 0.99$ for each assay (Fig. 3). As with conventional PCR, large amounts of DNA ( $\approx 100 \mathrm{ng} / \mu \mathrm{l}$ or higher) occasionally would result in a negative reaction (no 2 nd derivative- $C_{T}$ value) (data not shown). The lower limits of detection, determined by serial dilutions of DNA, ranged from 0.053 to $0.53 \mathrm{pg}$ for $P$. graminis DNA, 0.016 to $0.16 \mathrm{pg}$ for $P$. recondita $\mathrm{f}$. sp secalis DNA, 0.1 to $1.0 \mathrm{pg}$ for $P$. striiformis DNA, and 0.067 to $0.67 \mathrm{pg}$ for $P$. triticina DNA over multiple repetitions.

Assay specificity. To test possible interference of FAM probe specificity from DNA of more than one rust fungal species present in the same PCR assay, $P$. graminis and $P$. triticina DNA were combined in single-tube mixtures $(0: 100,10: 90,25: 75,75: 25$, 90:10, and 100:0\%) for a combined total of $500 \mathrm{pg} \mathrm{\mu l}^{-1}$ of fungal DNA. Mixtures were tested with either the $P$. graminis or the $P$. triticina FAM probe. Both probes showed a decrease in the $\mathrm{C}_{\mathrm{T}}$ value as the concentration of the DNA specific to the probe increased (Fig. 4). $\mathrm{C}_{\mathrm{T}}$ values for the $P$. graminis assay resulted in a regression line with an $r^{2}$ of 0.99 and a reaction efficiency of $96 \%$. The results for the $P$. triticina assay were similar, with the regression line giving an $r^{2}$ of 0.90 and the reaction efficiency of $93 \%$. Neither assay gave a positive $\mathrm{C}_{\mathrm{T}}$ value for nontarget DNA (Fig. 4).

Specificity of primer pairs and probes was evaluated further through database searches and analysis of published sequences. BLASTN searches of nucleotide databases were done for the primer pairs and FAM probes for each of the four assays. Among the first 100 matches, the forward primer ITS1rustF10d showed $100 \%$ identity to Puccinia and Uromyces spp. and to some Tilletia spp. and other nonfungal species. However, the reverse primer ITS1rustR3c showed $100 \%$ identity only to Puccinia and Uro-

TABLE 3. Specificity of real-time polymerase chain reaction (PCR) assays for Puccinia graminis, $P$. recondita, $P$. striiformis, and $P$. triticina

\begin{tabular}{|c|c|c|c|c|c|c|c|c|c|c|c|c|c|}
\hline \multirow[b]{2}{*}{ Rust fungal species } & \multicolumn{6}{|c|}{ Real-time PCR ${ }^{\mathrm{a}}$} & \multirow[b]{2}{*}{ Rust fungal species } & \multicolumn{6}{|c|}{ Real-time $\mathrm{PCR}^{\mathrm{a}}$} \\
\hline & $\mathrm{I}^{\mathrm{b}}$ & $\mathrm{S}^{\mathrm{c}}$ & $\mathrm{Pg}^{\mathrm{d}}$ & $\operatorname{Pr}^{\mathrm{e}}$ & $\operatorname{Ps}^{\mathrm{f}}$ & $\mathrm{Pt}^{\mathrm{g}}$ & & $\mathrm{I}^{\mathrm{b}}$ & $\mathrm{S}^{\mathrm{c}}$ & $\mathrm{Pg}^{\mathrm{d}}$ & $\operatorname{Pr}^{\mathrm{e}}$ & $\mathrm{Ps}^{\mathrm{f}}$ & $\mathrm{Pt}^{\mathrm{g}}$ \\
\hline P. graminis & & & & & & & P. triticina & & & & & & \\
\hline 78-21-BB463 & + & + & + & - & - & - & 99NC28-1 & + & + & - & - & - & + \\
\hline 75WA205A & + & + & + & - & - & - & 93WA504 & + & + & - & - & - & + \\
\hline 91MEX647 & + & + & + & - & - & - & 82TX176 & + & + & - & - & - & + \\
\hline 72CAN1321A & + & + & + & - & - & - & $82 \mathrm{MN} 246$ & + & + & - & - & - & + \\
\hline 73VA441A & + & + & + & - & - & - & 87NY678 & + & + & - & - & - & + \\
\hline 93NY224B & + & + & + & - & - & - & 00CA135 & + & + & - & - & - & + \\
\hline $91 \mathrm{KS} 60 \mathrm{~A}$ & + & + & + & - & - & - & $90 \mathrm{KS} 285$ & + & + & - & - & - & + \\
\hline 91WA496A & + & + & + & - & - & - & 00EGY38B & + & + & - & - & - & + \\
\hline 56SD37B & + & + & + & - & - & - & 00EGY200C & + & + & - & - & - & + \\
\hline 84FL680 & + & + & + & - & - & - & 98EGY166C & + & + & - & - & - & + \\
\hline $74 \mathrm{KS} 264 \mathrm{~A}$ & + & + & + & - & - & - & 98EGY151C & + & + & - & - & - & + \\
\hline 80MN633B & + & + & + & - & - & - & 99SPN40AO & + & + & - & - & - & + \\
\hline HSZ0802 & + & + & + & - & - & - & 03SPN24AO & + & + & - & - & - & + \\
\hline HSZ0803 & + & + & + & - & - & - & HSZ0745 & + & + & - & - & - & + \\
\hline HSZ0753 & + & + & + & - & - & - & P. andropogonis & & & & & & \\
\hline HSZ0009 & + & + & + & - & - & - & HSZ0261 & + & + & - & - & - & - \\
\hline P. recondita & & & & & & & HSZ0222 & + & + & - & - & - & - \\
\hline 80WV271 & + & + & - & + & - & - & HSZ0237 & + & + & - & - & - & - \\
\hline $82 \mathrm{WI} 47$ & + & + & - & + & - & - & HSZ0227 & + & + & - & - & - & - \\
\hline $91 \mathrm{TX} 9503$ & + & + & - & + & - & - & P. bromina & & & & & & \\
\hline HSZ0698 & + & + & - & + & - & - & HSZ0663 & + & + & - & - & - & - \\
\hline ANK9958 & + & + & - & + & - & - & HSZ0664 & + & + & - & - & - & - \\
\hline ANK9974 & + & + & - & + & - & - & P. arrhenathericola & & & & & & \\
\hline P. striiformis & & & & & & & HSZ0659 & + & + & - & - & - & - \\
\hline PSH14 & + & + & - & - & + & - & P. triseti & & & & & & \\
\hline PSH31 & + & + & - & - & + & - & HSZ0700 & + & + & - & - & - & - \\
\hline PST29 & + & + & - & - & + & - & P. coronata & & & & & & \\
\hline PST78 & + & + & - & - & + & - & HSZ0425 & + & + & - & - & - & - \\
\hline $52 / 99$ & + & + & - & - & + & - & P. persistens & & & & & & \\
\hline HSZ0722 & + & + & - & - & + & - & HSZ0688 & + & + & - & - & - & - \\
\hline HSZ0724 & + & + & - & - & + & - & Tranzschelia arthurii & + & - & - & - & - & - \\
\hline & & & & & & & T. fusca & + & - & - & - & - & - \\
\hline
\end{tabular}

a A threshold $(\mathrm{Ct})$ value of 30 was used; $+=$ positive and $-=$ negative.

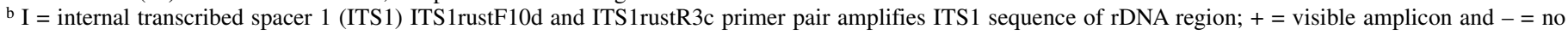
visible amplicon by gel electrophoresis.

c $\mathrm{S}=$ internal standard assay using StdLSUF5a and StdLSUR2a primer pair with TexasRed probe.

${ }^{\mathrm{d}} \mathrm{Pg}=\mathrm{ITS} 1$ rustF10d and ITS1rustR3c primer pair, and $P$. graminis FAM probe.

e $\operatorname{Pr}=$ ITS1rustF10d and ITS1rustR3c primer pair, and $P$. recondita $\mathrm{f}$. sp. secalis FAM probe.

${ }^{\mathrm{f}} \mathrm{Ps}=\mathrm{ITS} 1 \mathrm{rustF} 10 \mathrm{~d}$ and ITS1rustR3c primer pair, and $P$. striiformis FAM probe.

g Pt $=$ ITS1rustF10d and ITS1rustR3c primer pair, and $P$. triticina FAM probe. 
myces spp. For the $P$. graminis species FAM probe, a $100 \%$ identity was found only to $P$. graminis, with the next closest sequence having 12 single-base-pair differences to homologous ITS1 DNA sequence. The same degree of specificity was found for the $P$. recondita $\mathrm{f}$. sp. secalis FAM probe, with $100 \%$ identity only to that species and the next closest sequence also having 12 singlebase-pair differences. However, BLASTN results showed fewer single-base-pair differences for the other two FAM probes. The $P$. striiformis-specific FAM probe showed a 1-bp difference to $P$. monoica homologous ITS1 DNA sequence and the related species $P$. thlaspeos and P. consimilis, and two single-base-pair differences to $P$. coronata f. sp. avenae, $P$. allii, $U$. scillarum, and $U$. reichertii. The $P$. triticina FAM probe showed only 1-bp difference to $P$. sessilis, but $\geq 9$ single-base-pair differences to all other organisms.

Assay application. Real-time PCR analysis confirmed sample HSZ0887 as P. graminis, as well as P. striiformis for HSZ0886 and HSZ0885 (Table 4). Sample HSZ0882 was positively identified as $P$. striiformis by real-time PCR, which had conflicting results between the field observation and urediniospore morphological characteristics. Finally, two of the six samples were negative with all real-time PCR assays, except the internal controls indicating that these samples were rust fungi other than the four species tested. Recently, a $P$. coronata real-time PCR probe was developed, and these two samples tested positive (data not shown). In addition, the ITS region of all six samples was sequenced, and confirmed the real-time PCR results.

\section{DISCUSSION}

The objective of this study was to develop rapid real-time PCR assays to identify and detect four common cereal and grass rust pathogens, Puccinia graminis, $P$. recondita f. sp. secalis, $P$. striiformis, and P. triticina. Each assay was $100 \%$ specific and consistently detected DNA concentrations $\leq 1.0 \mathrm{pg}$. This is equivalent to less than five urediniospores (4). The highly sensitive, specific, and rapid assays described here, as well as the portability of some SmartCycler devices (31), make the assays ideal for detecting the four rust pathogens in the early stages of disease development, and can be developed for other rust fungi. This report is the first to describe detection and discrimination of these four rust pathogens using real-time PCR.

Sequence similarities and differences in the ITS1 region were useful in discriminating DNA of $P$. graminis, $P$. recondita $\mathrm{f}$. sp. secalis, $P$. striiformis, and $P$. triticina. The large number of sequences we obtained from a variety of collections of each of the four rust pathogens increased our confidence in the specificity of the assays. Furthermore, BLASTN searches with the species-specific FAM probe sequences also have shown these assays to be specific for their intended target. White et al. (36) suggested that rDNA
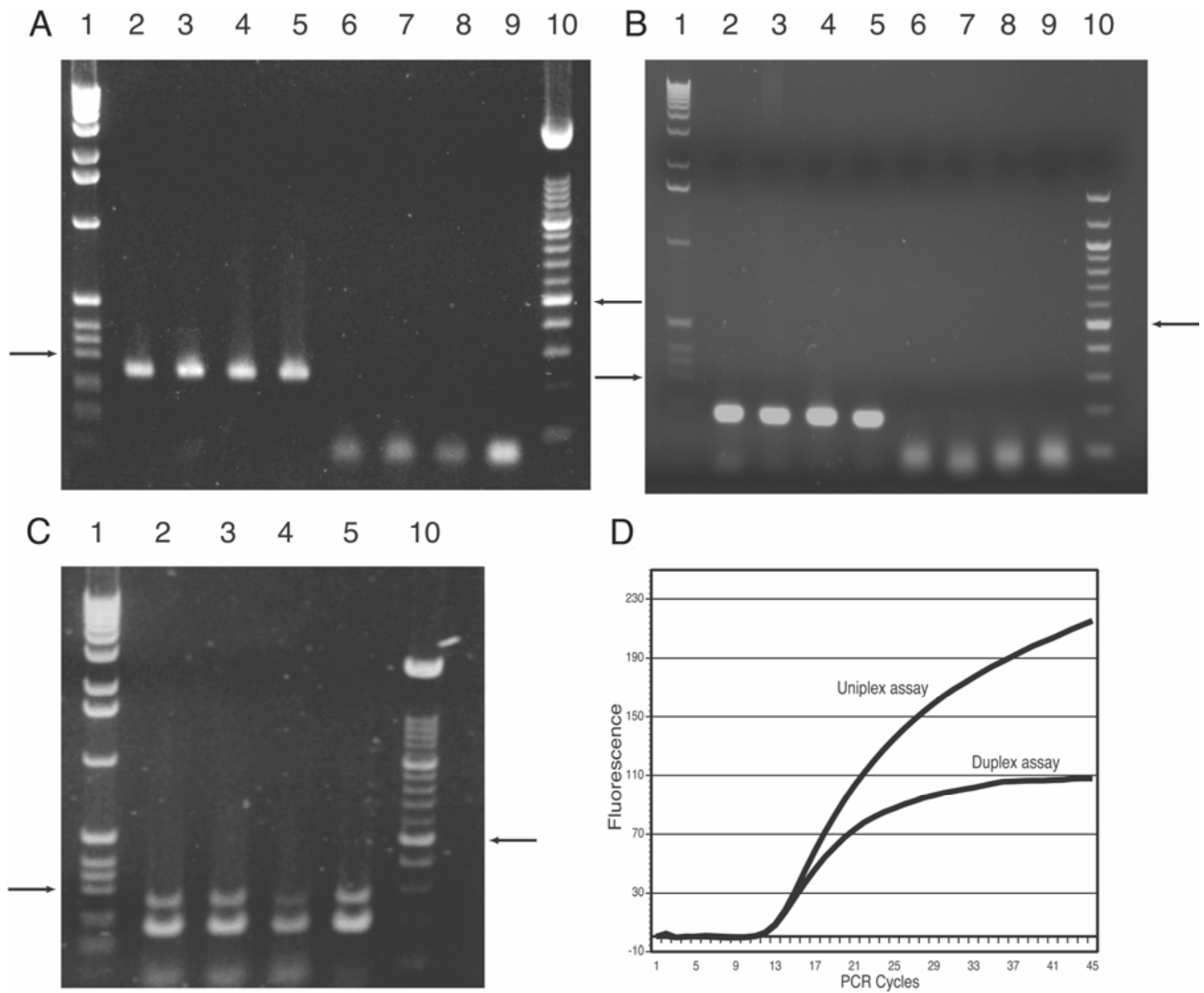

D

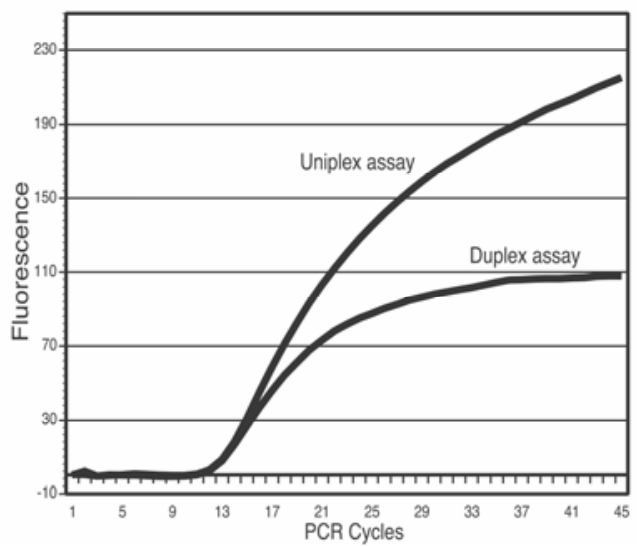

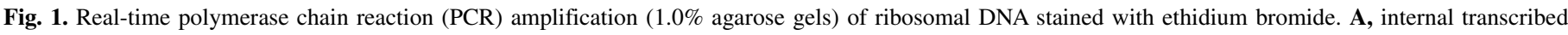

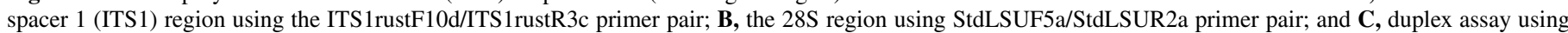

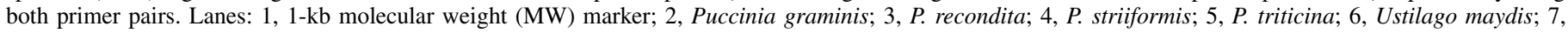

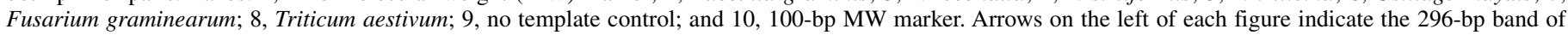

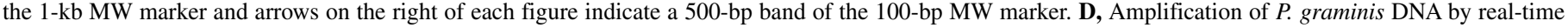

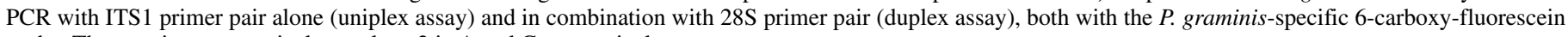
probe. The reactions are equivalent to lane 2 in $\mathrm{A}$ and $\mathrm{C}$, respectively. 
could be useful for differentiating species because of the low evolutionary pressure on this area of the DNA that has resulted in its duplication in the genome. The use of ITS regions 1 and 2 for the production of specific primers has proven to be a successful strat- egy for developing diagnostic assays for many plant-pathogenic fungi $(5,9,14)$.

The specificity of the assays for each rust fungal species held true for samples collected at diverse locations, times, and sources.
ITS1

A

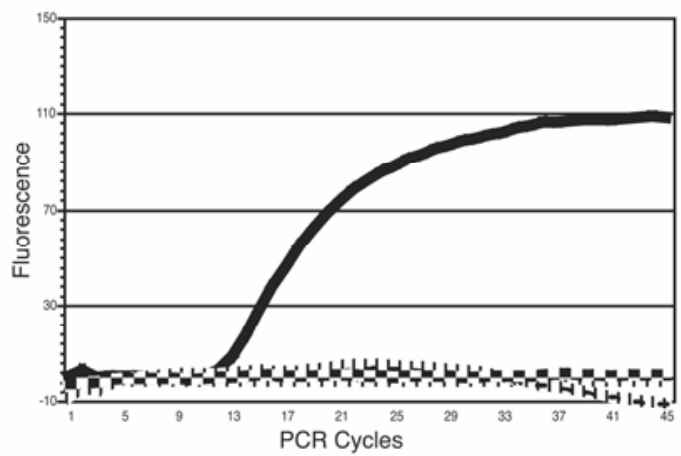

B

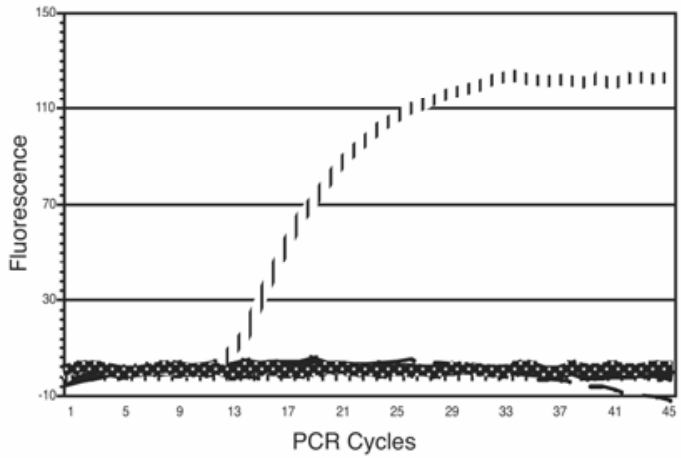

C

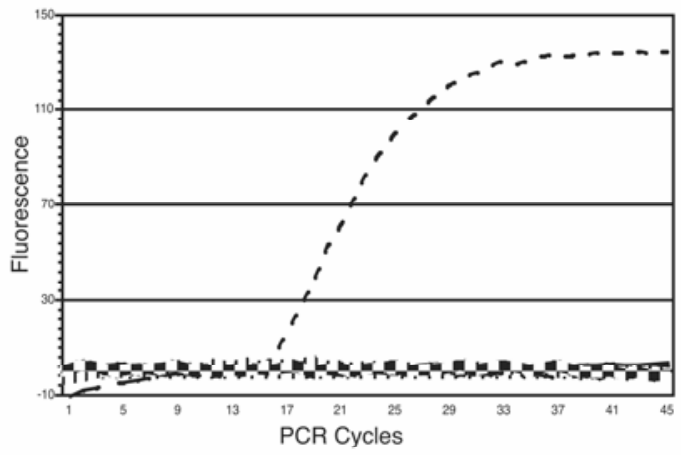

D

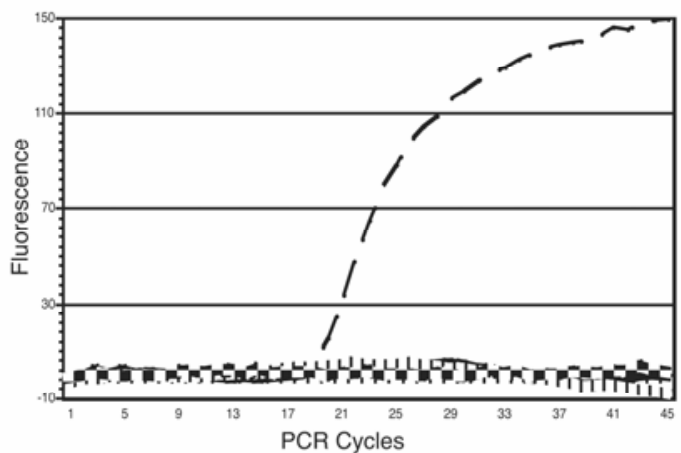

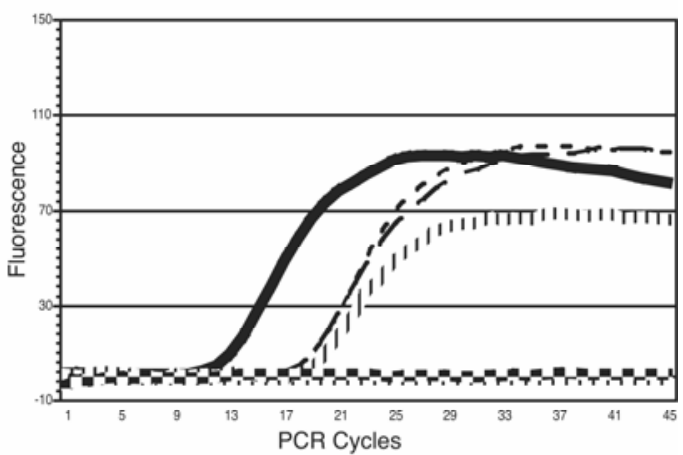
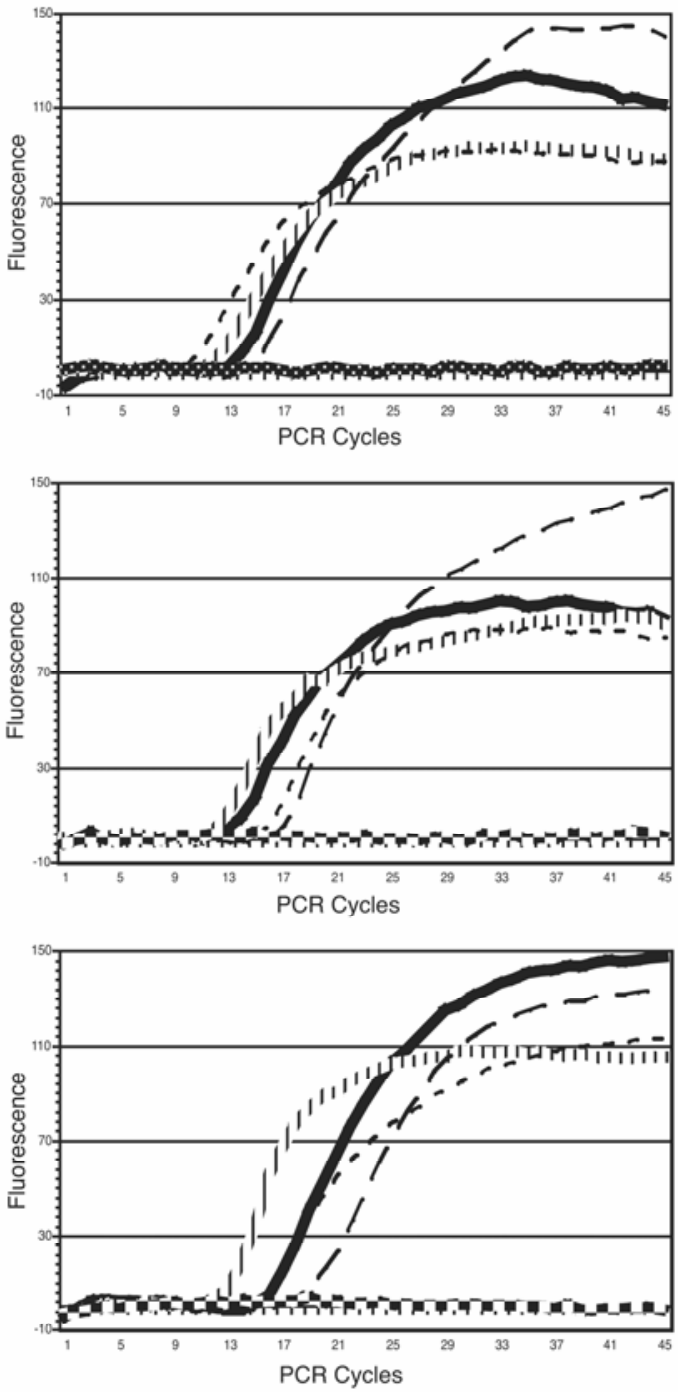

Fig. 2. Real-time polymerase chain reaction (PCR) duplex assays containing DNA from the four Puccinia spp., plus Triticum aestivum. Assay results in the internal transcribed spacer 1 (ITS1) column were amplified with the ITS1rustF10d/ITS1rustR3c primer pair along with 6-carboxy-fluorescein probes specific to each rust fungal species: A, Puccinia graminis; B, P. recondita f. sp. secalis; $\mathbf{C}$, P. striiformis; and D, P. triticina. Each assay was specific to the intended rust fungal species. Assays in the $28 \mathrm{~S}$ column were the internal standard assays duplexed with the adjacent ITS1 assay. Internal standard assays utilized the StdLSUF5a/StdLSUR2a primer pair along with the TexasRed probe for all assays. Only rust fungal DNA was amplified by the StdLSUF5a/StdLSUR2a primer pair. 
Known isolates of $P$. graminis tested from Canada, Mexico, the Czech Republic, and throughout the United States from 1956 until the present all tested positive only with the $P$. graminis-specific assay. For the most closely related species, the leaf rust fungi $P$. recondita f. sp. secalis and $P$. triticina (formerly $P$. recondita $f$. sp. tritici), each assay was specific to the particular species, and did not detect other closely related leaf rust fungal species found on Bromus, Arrhenatherum, Trisetum, or Elytrigia grasses. These results suggest the FAM probes are specific within the $P$. recondita species complex for the two rust fungal species evaluated in this study. Furthermore, the use of leaf tissue samples provided additional support for assay specificity because any number of pathogens or saprophytes could have been present on leaf tissue samples along with the rust fungus of interest.

Individual FAM probes also were able to distinguish and quantify DNA from individual species from a mixture of species DNA. Therefore, the utility of the assays could be expanded to study competition between rust fungi on a single plant, or detecting and quantifying species from environmental samples (rain or air), where the host is unknown and a variety of organisms may be present. However, the linearity of the standard curves in the sample mixtures was more variable and slightly less efficient than assays using DNA of a single species. A PCR assay is $100 \%$ efficient if each cycle results in a doubling of the DNA concentration. However, few reactions are $100 \%$ efficient, and differences in PCR efficiency between samples being tested and an independent standard curve can greatly affect the quantitative measurement $(6,17,22,23,25)$. Furthermore, the error in DNA quantification increased due to the logarithmic transformation in calculations (39).
Therefore, caution should be taken when surmising pathogen DNA concentration from a real-time PCR assay when mixtures of species may be present.

The amount of DNA as indicated in our assays may be a useful measure of fungal growth. However, DNA concentration may not relate directly to growth in fungal mass in plant tissues that contain various sizes of hyphae and sporophores as well as spores. Current methods, which rely on assays for glucosamine as an indication of chitin $(1,18,35)$ or for the polyoles arabite and mannite that appear as constituents of urediniospores (3), also are limited by variation in fungal tissue and are more labor intensive. In the end, the accuracy, sensitivity, and ease of real-time PCR DNA quantification are a clear advance to current methods. Future research will be needed to correlate disease development with changes in DNA concentration. The assays developed in this study will be useful in these studies.

Equal concentrations of 28S and ITS1 primer pairs and both FAM and TexasRed probes resulted in similar $C_{T}$ values for both the $28 \mathrm{~S}$ and ITS1 assays. $\mathrm{C}_{\mathrm{T}}$ values for the $28 \mathrm{~S}$ assay indicated the amount and quality of rust fungal DNA present in negative ITS1 FAM probe reactions. In this study, we chose to keep primer pairs and probes in equal concentration to verify the presence of fungal DNA in a given sample and did not test duplex assays with lower $28 \mathrm{~S}$ primer pair concentrations. Therefore, the amount of time for the confirmation of a negative result was roughly the same as for positive reactions. Positive results on the SmartCycler for the $28 \mathrm{~S}$ region $\left(\mathrm{C}_{\mathrm{T}}\right.$ values $\left.>0\right)$, as well as for the ITS1 region, always were consistent with those of an agarose gel run at the end of each reaction. Fluorescence in duplex assays was reduced rela-

\section{A}

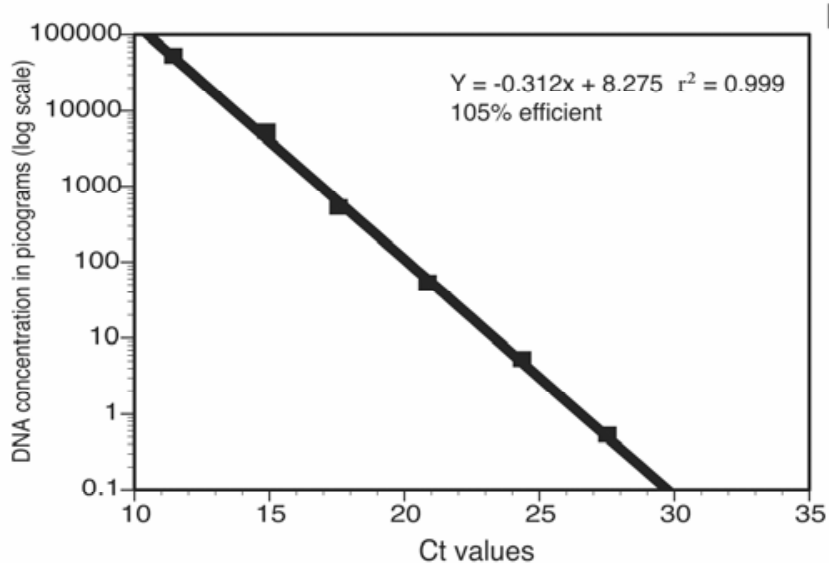

C

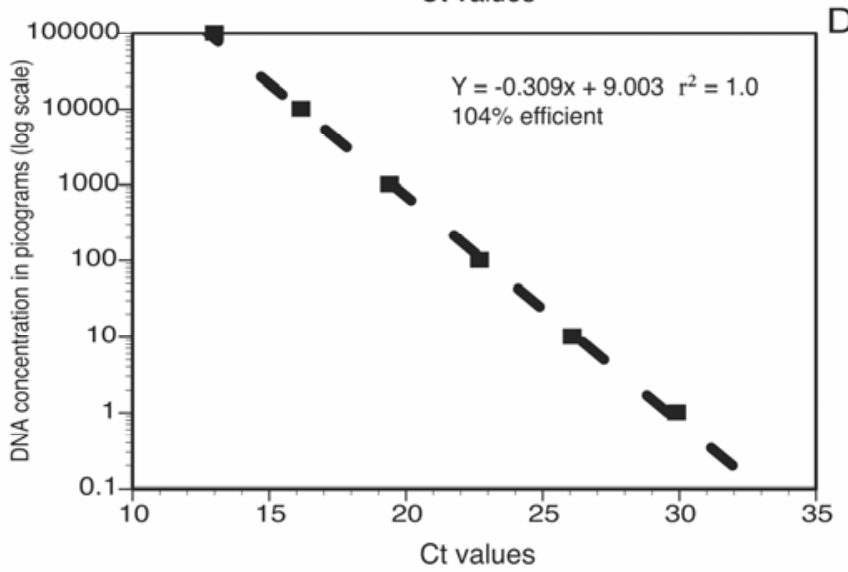

B
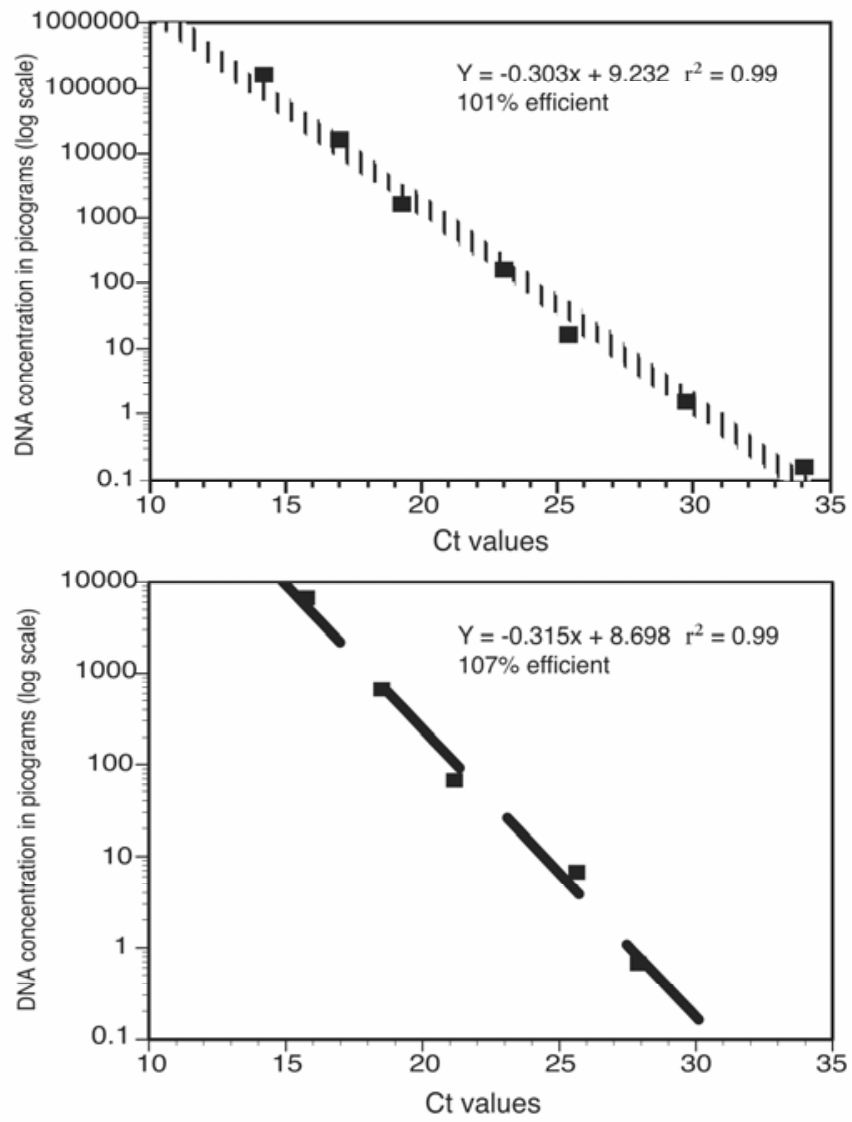

P. graminis 1111111111 P. recondita

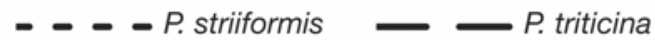

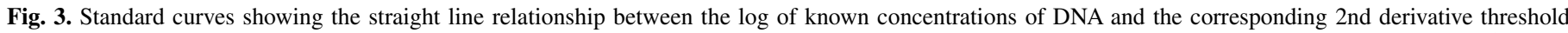

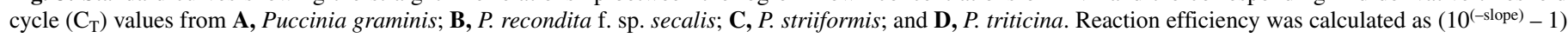
$* 100$. 
tive to uniplex assays of the same DNA sample (Fig. 2D), suggesting that the amount of total amplicon was reduced $(7,10)$. However, because the $\mathrm{C}_{\mathrm{T}}$ value was not affected, the advantages of having primer pairs and probes in equal concentrations were not lost. These results further suggest that detection of target DNA in very low concentrations may be more reliable in uniplex assays.

We found that FAM probes need a minimum of three singlebase-pair differences to maintain specificity among closely re-

A

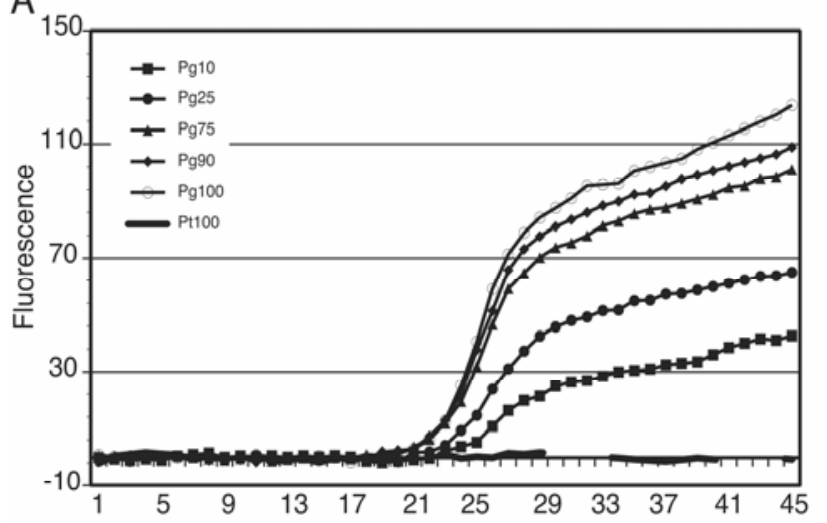

B

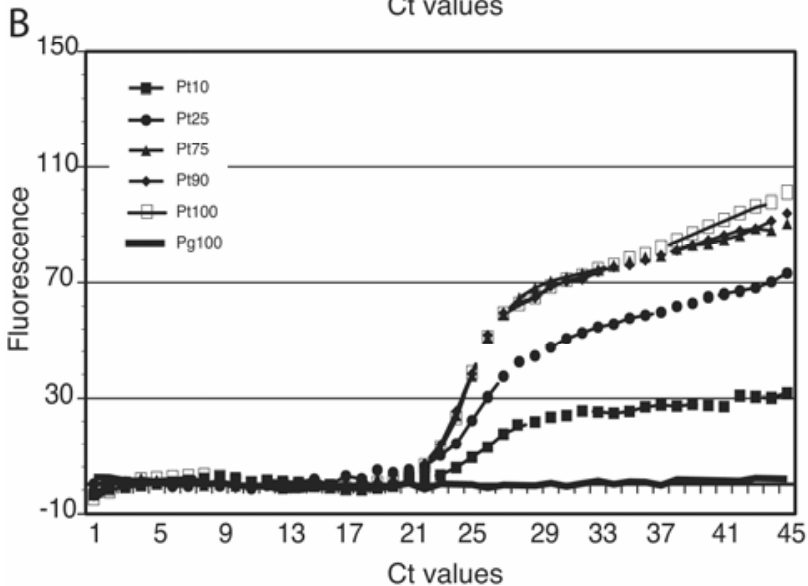

P. graminis lated rust fungal species within the confines of the PCR protocol. In this study, a preliminary $P$. striiformis probe having only two single-base-pair differences detected both $P$. triticina and $P$. recondita $\mathrm{f}$. $\mathrm{sp}$. secalis. To maintain the consistency in PCR conditions among assays, lengthening of the $P$. striiformis FAM probe to include an additional base pair difference made the $P$. striiformis FAM probe species specific. However, we also were successful in increasing specificity of the $P$. striiformis FAM probe with only two single-base-pair differences by increasing the
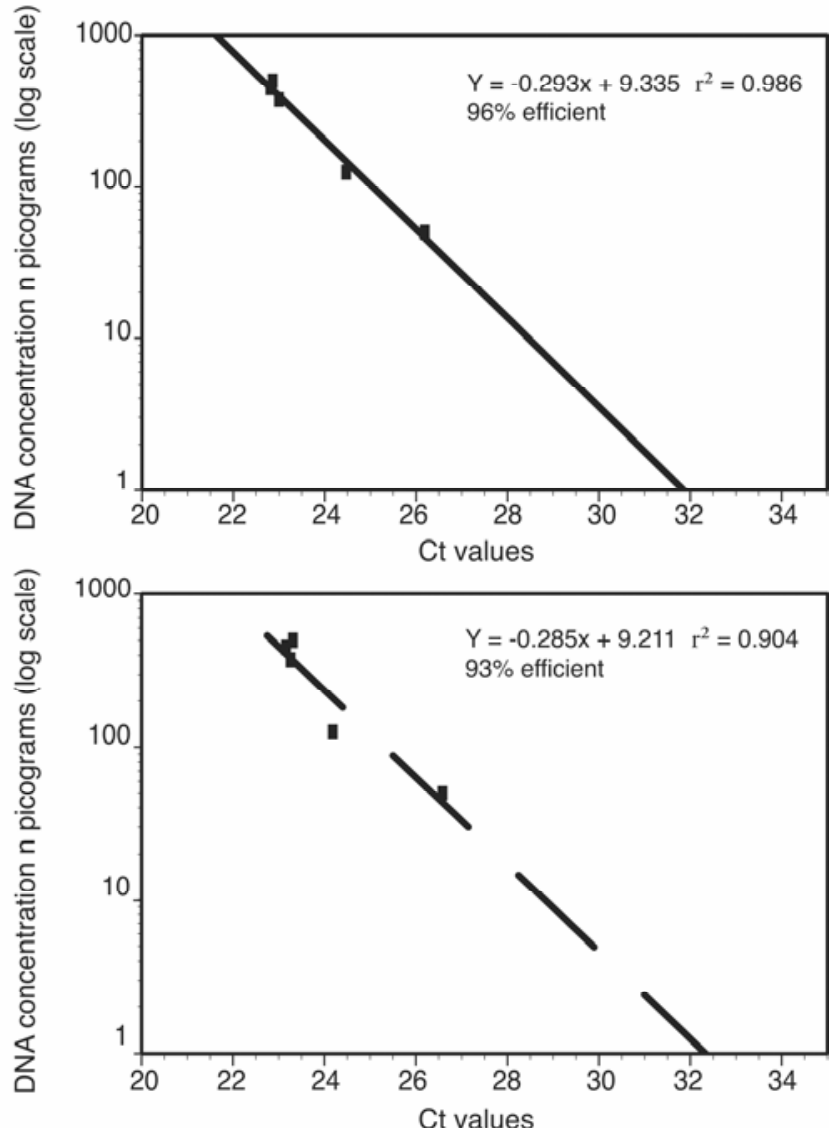

P. triticina

Fig. 4. Real-time polymerase chain reaction uniplex assays containing DNA from Puccinia graminis and P. triticina in mixtures totaling 500 pg of DNA at $100 \%$ $(500 \mathrm{pg}), 90 \%(450 \mathrm{pg} ; 50 \mathrm{pg}), 75 \%(375 \mathrm{pg} ; 125 \mathrm{pg}), 25 \%$ (125 pg; $375 \mathrm{pg}$ ), and 10\% (50 pg; $450 \mathrm{pg}$ ) for both rust fungal species. 6-Carboxy-fluorescein probes specific to A, P. graminis and B, P. triticina were utilized in each mixture with corresponding standard curves to the right of each assay. Reaction efficiency was calculated as $\left(10^{\text {(-slope) }}-1\right) * 100 . \mathrm{C}_{\mathrm{T}}=$ threshold cycle.

TABLE 4. Use of real-time polymerase chain reaction (PCR) to identify unknown Puccinia spp. from pasture grasses

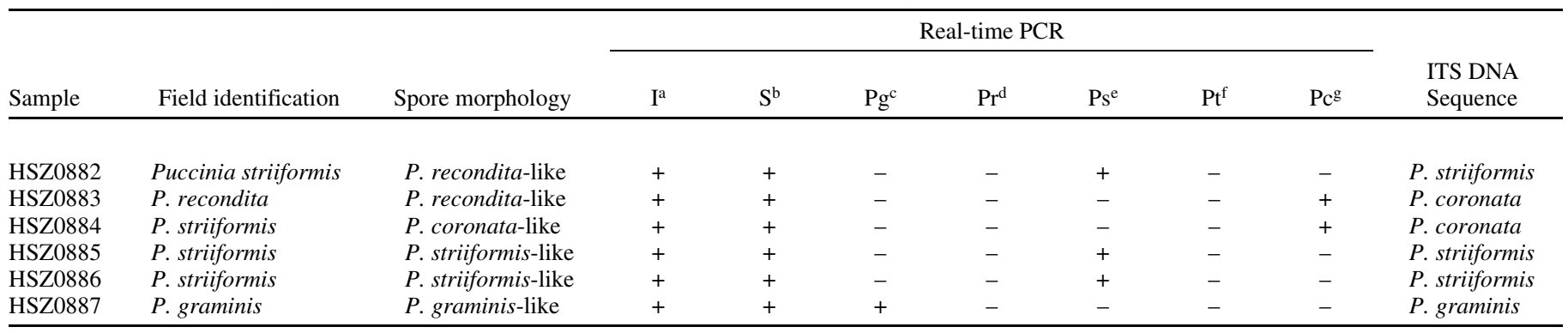

${ }^{\mathrm{a}}$ I $=$ internal transcribed spacer 1 (ITS1) ITS1rustF10d and ITS1rustR3c primer pair amplifies ITS1 sequence of rDNA region; $+=$ visible amplicon and $-=$ no visible amplicon by gel electrophoresis.

${ }^{\mathrm{b}} \mathrm{S}=$ internal standard assay using StdLSUF5a and StdLSUR2a primer pair with TexasRed probe.

${ }^{\mathrm{c}} \mathrm{Pg}=\mathrm{ITS} 1 \mathrm{rustF} 10 \mathrm{~d}$ and ITS1rustR3c primer pair, and $P$. graminis FAM probe.

${ }^{\mathrm{d}} \mathrm{Pr}=\mathrm{ITS} 1$ rustF10d and ITS1rustR3c primer pair, and $P$. recondita $\mathrm{f}$. sp. secalis FAM probe.

${ }^{\mathrm{e}} \mathrm{Ps}=\mathrm{ITS} 1$ rustF10d and ITS1rustR3c primer pair, and $P$. striiformis FAM probe.

${ }^{\mathrm{f}} \mathrm{Pt}=\mathrm{ITS} 1$ rustF10d and ITS1rustR3c primer pair, and $P$. triticina $\mathrm{FAM}$ probe.

${ }^{\mathrm{g}} \mathrm{Pc}=\mathrm{ITS} 1$ rustF10d and ITS1rustR3c primer pair, and $P$. coronata FAM probe. 
annealing temperature of the assay. Additionally, locked nucleic acid hybridization probes have been shown to distinguish single nucleotide polymorphisms using real-time PCR (13).

$P$. graminis and $P$. striiformis TaqMan assays were used successfully to distinguish stem rust and stripe rust on pasture grasses. It should be noted that the $P$. striiformis FAM probe does show close sequence similarity to several rust fungi, with 1-bp difference to $P$. monoica and the related species $P$. thlaspeos and $P$. consimilis, and two single-base-pair differences to $P$. coronata f. sp. avenae, $P$. allii, $U$. scillarum, and $U$. reichertii. The $P$. striiformis FAM probe did not show positive results when tested

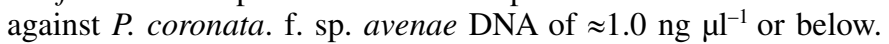
Weak false positive results occasionally were observed with higher DNA concentrations (data not shown). However, knowledge of the fungal DNA concentration and the host can eliminate some or all other rust fungal species that may show a false positive reaction.

PCR assay conditions and primers were optimized to DNA from as many rust fungi as possible, and not optimized for individual rust fungal species. To accomplish this, several primer pair combinations were analyzed for both the rust-fungus-specific primer pair and internal standard primer pair. The final primer pairs used for each assay were chosen based on low $\mathrm{C}_{\mathrm{T}}$ values in uniplex and duplex assays and for compatibility with as many other rust fungi as possible. The flexibility built into the assay allows the assay to be adapted to other rust fungi simply by designing a new species-specific TaqMan probe. Variability outside the region in which the probes were designed can be used to generate primers to further differentiate rust fungal species to some extent. The goals of this study, however, were to maximize the versatility and simplicity by using standardized PCR conditions while maintaining assay specificity. Although knowledge of the host reduces doubt over possible false-positive results, application of the assay to spore identification from environmental samples, such as rain or air samples, may require greater primer specificity.

\section{ACKNOWLEDGMENTS}

Mention of a trademark name or proprietary product does not constitute a guarantee by the United States Department of Agriculture or the University of Minnesota. We thank K. P. Nguyen for her technical assistance; D. Garvin for providing wheat DNA; W. Bushnell for critical comments on the manuscript; P. Hamm of Oregon State University, Hermiston, for providing infected pasture grass leaves; and A. Roelfs of the United States Department of Agriculture-Agricultural Research Service, Cereal Disease Laboratory, St. Paul, MN, for light microscopic characterization of urediniospores.

\section{LITERATURE CITED}

1. Allen, P. J. 1959. Metabolic considerations of obligate parasitism. Pages 119-129 in: Plant Pathology-Problems and Progress, 1908-1958. C. S. Holton, G. W. Fisher, R. W. Fulton, H. Hart, and S. E. A. McCallan, eds. University of Wisconsin Press, Madison.

2. Anikster, Y., Szabo, L. J., Eilam, T., Manisterski, J., Koike, S. T., and Bushnell, W. R. 2004. Morphology, life cycle biology, and DNA sequence analysis of rust on garlic and chives from California. Phytopathology 94:569-577.

3. Artemenko, E. N., Stekolshchikov, M. V., and Chkanikov, D. I. 1993. Possibility of determining the amount of spores (sporulation) of stem and leaf rusts of wheat based on the accumulation of polyoles in infected leaves. Mycol. Phytopathol. 25:540-545.

4. Backlund, J. E., and Szabo, L. J. 1993. Physical characteristics of the genome of the phytopathogenic fungus Puccinia graminis. Curr. Genet. 24:89-93.

5. Bates, J. A., and Taylor, E. J. A. 2001. Scorpion ARMS primers for SNP real-time PCR detection and quantification of Pyrenophora teres. Mol. Plant Pathol. 2:275-280.

6. Bustin, S. A. 2002. Quantification of mRNA using real-time reverse transcription PCR (RT-PCR): trends and problems. J. Mol. Endocrinol. 29:23-39.

7. Campbell, M. S., and Wright, A. C. 2003. Real-time PCR analysis of Vibrio vulnificus from oysters. Appl. Environ. Microbiol. 69:7137-
7144.

8. Fraaije, B. A., Lovell, D. J., Coelho, J. M., Baldwin, S., and Hollomon, D. W. 2001. PCR-based assays to assess wheat varietal resistance to blotch (Septoria tritici and Stagonospora nodorum) and rust (Puccinia striiformis and Puccinia recondita) diseases. Eur. J. Plant Pathol. 107:905-917.

9. Frederick, R. D., Snyder, C. L., Peterson, G. L., and Bonde, M. R. 2002. Polymerase chain reaction assays for the detection and discrimination of the soybean rust pathogens Phakopsora pachyrhizi and P. meibomiae. Phytopathology 92:217-227.

10. Gachon, C., Mingam, A., and Charrier, B. 2004. Real-time PCR: what relevance to plant studies? J. Exp. Bot. 55:1445-1454.

11. Henson, J. M., and French, R. 1993. The polymerase chain reaction and plant disease diagnosis. Annu. Rev. Phytopathol. 31:81-109.

12. Heuser, T., and Zimmer, W. 2002. Quantitative analysis of phytopathogenic ascomycota on leaves of pedunculate oaks (Quercus robur L.) by real-time PCR. FEMS Microbiol. Lett. 209:295-299.

13. Johnson, M. P., Haupt, L. M., and Griffiths, L. R. 2004. Locked nucleic acid (LNA) single nucleotide polymorphism (SNP) genotype analysis and validation using real-time PCR. Nucleic Acids Res. 32:e55.

14. Lees, A. K., Cullen, D. W., Sullivan, L., and Nicolson, M. J. 2002. Development of conventional and quantitative real-time PCR assays for the detection and identification of Rhizoctonia solani AG-3 in potato and soil. Plant Pathol. 51:293-302.

15. Leonard, K. J., and Szabo, L. J. 2005. Stem rust of small grains and grasses caused by Puccinia graminis. Mol. Plant. Pathol. 6:99-111.

16. Liu, J. Q., and Kolmer, J. A. 1998. Genetics of stem rust resistance in wheat cvs. Pasqua and AC Taber. Phytopathology 88:171-176.

17. Marubini, E., Verderio, P., Raggi, C. C., Pazzagli, M., and Orlando, C. 2004. Statistical diagnostics emerging from external quality control of real-time PCR. Int. J. Biol. Mark. 19:141-146.

18. Mayama, S., Rehfeld, D. W., and Daly, J. M. 1975. A comparison of the development of Puccinia graminis tritici in resistant and susceptible wheat based on glucosamine content. Physiol. Plant Pathol. 7:243257.

19. Niks, R. E. 1989. Morphology of infection structures of Puccinia striiformis var. dactylidis. Neth. J. Plant Pathol. 95:171-175.

20. Okubara, P. A., Schroeder, K. L., and Paulitz, T. C. 2005. Real-time polymerase chain reaction: applications to studies on soilborne pathogens. Can. J. Plant Pathol. 27:300-313.

21. O'Sullivan, C. E., Kasai, M., Francesconi, A., Petraitis, V., Petraitiene, R., Kelaher, A. M., Sarafandi, A. A., and Walsh, T. J. 2003. Development and validation of a quantitative real-time PCR assay using fluorescence resonance energy transfer technology for detection of Aspergillus fumigatus in experimental invasive pulmonary aspergillosis. J. Clin. Microbiol. 41:5676-5682.

22. Peirson, S. N., Bulter, J. N., and Foster, R. G. 2003. Experimental validation of novel and conventional approaches to quantitative real-time PCR data analysis. Nucleic Acids Res. 31:e73.

23. Pfaffl, M. W. 2001. A new mathematical model for relative quantification in real-time RT-PCR. Nucleic Acids Res. 29:e45.

24. Qi, M., and Yang, Y. 2002. Quantification of Magnaporthe grisea during infection of rice plants using real-time polymerase chain reaction and northern blot/phosphoimaging analyses. Phytopathology 92:870-876.

25. Ramakers, C., Ruijter, J. M., Lekanne Deprez, R. H., and Moorman, A. F. M. 2003. Assumption-free analysis of quantitative real-time polymerase chain reaction (PCR) data. Neurosci. Lett. 339:62-66.

26. Schaad, N. W., and Frederick, R. D. 2002. Real-time PCR and its application for rapid plant disease diagnostics. Can. J. Plant Pathol. 24:250258 .

27. Schaad, N. W., Opgenorth, D., and Gaush, P. 2002. Real-time polymerase chain reaction for one-hour on-site diagnosis of Pierce's disease of grape in early season asymptomatic vines. Phytopathology 92:721-728.

28. Schena, L., Nigro, F., and Ippolito, A. 2002. Identification and detection of Rosellinia necatrix by conventional and real-time Scorpion-PCR. Eur. J. Plant Pathol. 108:355-366.

29. Schena, L., Nigro, F., and Ippolito, A., and Gallitelli, D. 2004. Realtime quantitative PCR: a new technology to detect and study phytopathogenic and antagonistic fungi. Eur. J. Plant Pathol. 110:893-908.

30. Stubbs, R. W. 1985. Stripe rust. Pages 61-101 in: The Cereal Rusts, Vol. 2. A. P. Roelfs and W. R. Bushnell, eds. Academic Press, Orlando, FL.

31. Tomlinson, J. A., Boonham, N., Hughes, K. J. D., Griffen, R. L., and Barker, I. 2005. On-site DNA extraction and real-time PCR for detection of Phytophthora ramorum in the field. Appl. Environ. Microbiol. 71:6702-6710. 
32. Weber, R. W. S., Webster, J., and Engel, G. 2003. Phylogenetic analysis of Puccinia distincta and $P$. lagenophorae, two closely related rust fungi causing epidemics on Asteraceae in Europe. Mycol. Res. 107:15-24.

33. Wellings, C. R., Burdon, J. J., McIntosh, R. A., Wallwork, H., Raman, H., and Murry, G. M. 2000. A new variant of Puccinia striiformis causing stripe rust on barley and wild Hordeum species in Australia. Plant Pathol. 49:803.

34. Welty, R. E., and Azevedo, M. D. 1996. Seed yield responses of five selections of tall fescue susceptible or resistant to stem rust with or without propiconazole. Plant Dis. 80:625-628.

35. Whipps, J. M., Clifford, B. C., Roderick, H. W., and Lewis, D. H. 1980. A comparison of development of Puccinia hordei Ott. on normal and slow rusting varieties of barley (Hordeum vulgare L.) using analysis of fungal chitin and mannan. New Phytol. 85:191-199.

36. White, T. J., Bruns, T., Lee, S., and Taylor, J. 1990. Amplification and direct sequencing of fungal ribosomal RNA genes for phylogenetics. Pages 315-322 in: PCR Protocols: A Guide to Methods and Applications. M. A. Innis, D. H. Gelfand, J. J. Sninsky, and T. J. White, eds. Academic Press, Inc., San Diego, CA.

37. Wiese, M. V. 1987. Compendium of Wheat Diseases, 2nd ed. American Phytopathological Society, St. Paul, MN.

38. Winton, L. M., Stone, J. K., Watrud, L. S., and Hansen, E. M. 2002. Simultaneous one-tube quantification of host and pathogen DNA with real-time polymerase chain reaction. Phytopathology 92:112116.

39. Wiseman, G. 2002. State of the art and limitations of quantitative polymerase chain reaction. J. AOAC Int. 85:792-796.

40. Zambino, P. J., and Szabo, L. J. 1993. Phylogenetic relationships of selected cereal and grass rusts based on rDNA sequence analysis. Mycologia 85:401-414. 